\title{
UNRESOLVED SYMPTOMS IN ADULT POPULATION AFTER MILD SARS-COV2 INFECTIONS
}

\author{
AMINA ŠETA, SENKA DINAREVIĆ-MESIHOVIĆ, TIMUR ŠEČIĆ, MIRALEM ĐEŠEVIĆ**
}

Introduction: The coronavirus disease (COVID-19) in the past year and a half has become a worldwide pandemic. COVID-19 symptoms, severity and duration vary widely, with an increasing number of cases of unresolved and prolonged symptoms.

Objectives: This study aims to characterize unresolved symptoms of mild COVID-19 patients for a period of five months after disease onset, and potentially aid in disease management.

Methods: Seventy-five adult patients were involved in the study in the period October 2020-March 2021 in Eurofarm Centre Private Healthcare. Inclusion criteria required patients to be aged $\geq 18$ years, with positive SARS-CoV2 PCR test results and nonsevere symptoms which did not require hospitalization. The onset, duration and resolution of symptoms were analysed.

Results: 74.7\% (56/75), 69.3\% (52/75), 66.7\% (50/75) and 40.0\% (30/75) of the patients experienced headache, fever, muscle ache, or dry cough as covid symptom respectively. The majority of patients reported fatigue, 74.7\% (56/75). Smell and taste changes were experienced $3.9 \pm 2.4$ and $4.6 \pm 3.7$ days (mean $\pm S D$ ) after disease onset, respectively. Among prevalent symptoms, fever had the shortest duration (3.8 \pm 1.6 days), and taste and smell changes were the longest-lasting symptoms (22.2 \pm 17.6 and $26.9 \pm$ 19.7 days). At the five-month follow-up, 62.6\% (47/75) of the patients had at least one unresolved symptom, most commonly fatigue (57.3\%, 43/75), smell and taste changes (33.3\%, 25/75 and 10.6\%, 8/75 respectively), and breathing difficulties (10.6\%, 8/75).

Conclusion: Persistent symptoms after mild COVID-19 infection manifested in over half of the participants reporting at least one unresolved symptom after five months.

Keywords: COVID-19, SARS-COV2, SYMPTOMS DURATION, UNRESOLVED SYMPTOMS

\section{INTRODUCTION}

The coronavirus infection (SARSCoV2) is a worldwide pandemic, with more than 80 million cases and over a million deaths (1). SARS-CoV2 targets the human respiratory system at the onset of disease, with the most common symptoms being fever, shortness of breath, cough, malaise, muscle aches, headache, loss of smell or taste, sore throat, congestion, nausea/vomiting and diarrhea (2).

In general, adults with SARSCoV-2 infection can be grouped into the following severity of illness categories.

\footnotetext{
*Eurofarm Center Private Healthcare

Address:

Amina Š eta, dr. sci. med., specijalist interne medicine, dijabetolog i nutricionist

Eurofarm Center Private Healthcare

71000 Sarajevo, Fra Anđela Zvizdovića 1

Bosnia and Herzegovina

E-mail: aminagodinjak@gmail.com
}

However, the criteria for each category may overlap or vary across clinical guidelines and clinical trials, and a patient's clinical status may change over time. Asymptomatic or Presymptomatic Infection: Individuals who test positive for SARS-CoV-2 using a virologic test (i.e., a nucleic acid amplification test [NAAT] or an antigen test) but who have no symptoms that are consistent with COVID-19. Mild Illness: Individuals who have any of the various signs and symptoms of COVID-19 (e.g., fever, cough, sore throat, malaise, headache, muscle pain, nausea, vomiting, diarrhea, loss of taste and smell) but who do not have shortness of breath, dyspnea, or abnormal chest imaging. Moderate Illness: Individuals who show evidence of lower respiratory disease during clinical assessment or imaging and who have an oxygen saturation $\left(\mathrm{SpO}_{2}\right) \geq 94 \%$ on room air at sea level. Se- vere Illness: Individuals who have $\mathrm{SpO}_{2}$ $<94 \%$ on room air at sea level, a ratio of arterial partial pressure of oxygen to fraction of inspired oxygen $\left(\mathrm{PaO}_{2} / \mathrm{FiO}_{2}\right)$ $<300 \mathrm{mmHg}$, respiratory frequency $>30$ breaths/min, or lung infiltrates $>50 \%$. Critical Illness: Individuals who have respiratory failure, septic shock, and/ or multiple organ dysfunction (3). COVID-19 symptoms vary widely in severity and duration $(4,5)$.

Twelve most common symptoms of covid infection are: taste change, smell change, fever, dry cough, productive cough, muscle aches, headache, runny nose, sore throat, diarrhea, breathing difficulty and fever.

"Long COVID" is a phenomenon where patients have long-term unresolved symptoms (6). These could be prolonged symptoms of COVID-19, 
or a post-COVID syndrome for which dysfunction of the autonomic nervous system has been proposed, although further research is needed to establish the cause(s) $(7,8)$.

We find ourselves receiving more and more of those outpatients who experienced mild symptoms linked to COVID-19 such as smell and taste changes followed by a short period of convalescence (on the order of few days) (9). Subsequently they complained of a relapse with persistent symptoms, especially myalgia, intense fatigue, fever, shortness of breath, chest tightness, tachycardia, headaches and anxiety. It is worth noting that tachycardia and anxiety are not symptoms of COVID-19, but are very often reported by post COVID-19 patients (10). Only a few studies have analysed the symptoms' order of appearance, durations and lack of resolution $(10,11)$. This study aims to give better understanding of this phenomenon.

\section{OBJECTIVES}

This study aims to characterize unresolved symptoms of mild COVID-19 patients for a period of five months after disease onset, and potentially aid in disease management.

\section{MATERIALS AND METHODS}

Eligibility criteria included patients aged $\geq 18$ years with positive SARSCoV2 PCR test results and mild symptoms that did not require hospitalisation of these patients.

Disease onset was defined as the first appearance of any of the COVID-19 symptoms. "Number of days after disease onset" was calculated by subtracting the date of the first symptom to occur from the date of the symptom's appearance. Mean ( \pm standard deviation $(\mathrm{SD})$ ) was calculated for each symptom. Unresolved symptoms were unresolved at the five-months check-up. Duration was calculated from the onset and resolution dates of each symptom.

\section{RESULTS}

\section{Patients' characteristics}

Persisting symptoms of 75 post covid-19 infection patients were analysed. The mean age of the patients was $35.5 \pm$ 8.2 years (mean $\pm \mathrm{SD}), 63 \%(47 / 75)$ were male, $18.7 \%$ (14/75) reported high blood pressure, $13.3 \%(10 / 75)$ respiratory disease, $13.3 \%(10 / 75)$ cardiac disease and $16.0 \%(12 / 75)$ obesity. Fatigue appeared first in the majority of patients ie. $74.7 \%$ $(56 / 75)$.
Table 1.

Mild COVID-19 patients' baseline charateristics

\begin{tabular}{ll}
\hline Patients' characteristics & \\
\hline Age $(\overline{\mathrm{x}} \pm \mathrm{SD})$ & $35.5 \pm 8.2$ \\
Male, n (\%) & $63 \%(47 / 75)$ \\
\hline Comorbidities, n (\%) & $18.7 \%(14 / 75)$ \\
\hline Arterial hypertension & $13.3 \%(10 / 75)$ \\
Respiratory disease & $13.3 \%(10 / 75)$ \\
Cardiac disease & $16.0 \%(12 / 75)$ \\
Obesity & \\
\hline
\end{tabular}

Symptoms' duration and resolution

$74.7 \%(56 / 75)$ of the patients experienced headache, $69.3 \%(52 / 75)$ fever, $66.7 \%(50 / 75)$ muscle ache and $40.0 \%$ (30/75) of the patients experienced dry cough as covid symptom respectively. Fatigue was experienced in the majority of patients, $74.7 \%(56 / 75)$. Smell and taste changes were experienced $3.9 \pm 2.4$ and $4.6 \pm 3.7$ days (mean $\pm \mathrm{SD}$ ) after disease onset, respectively. Among prevalent symptoms, fever had the shortest duration (3.2 \pm 1.6 days), and taste and smell changes were the longest-lasting symptoms $(22.2 \pm 17.6$ and $26.9 \pm 19.7$ days). Longer recovery of the sense of smell correlated with the extent of smell change.

Table 2.

Symptoms' duration and resolution

\begin{tabular}{|c|c|c|c|}
\hline Symptom & Patients, n (\%) & Symptoms onset (days) & Symptoms duration (days) \\
\hline Headache & $56(74.7)$ & $2.1 \pm 1.9$ & $4.0 \pm 1.2$ \\
\hline Fever & $52(69.3)$ & $3.5 \pm 1.7$ & $3.2 \pm 1.6$ \\
\hline Muscle aches & $50(66.7)$ & $2.3 \pm 2.1$ & $4.5 \pm 2.7$ \\
\hline Dry cough & $30(40.0)$ & $4.1 \pm 1.5$ & $3.9 \pm 3.5$ \\
\hline Lack of appetite & $15(20.0)$ & $5.0 \pm 1.8$ & $4.1 \pm 3.9$ \\
\hline Runny nose & $42(67.2)$ & $2.6 \pm 2.4$ & $5.1 \pm 3.8$ \\
\hline Sore throat & $29(38.7)$ & $2.8 \pm 2.6$ & $4.3 \pm 2.1$ \\
\hline Taste change & $21(28.0)$ & $4.6 \pm 3.7$ & $22.2 \pm 17.6$ \\
\hline Fatigue & $56(74.6)$ & $1.4 \pm 1.1$ & $12.3 \pm 5.8$ \\
\hline Smell change & $29(38.7)$ & $3.9 \pm 2.4$ & $26.9 \pm 19.7$ \\
\hline Diarrhea & $26(34.7)$ & $3.1 \pm 2.3$ & $4.3 \pm 1.1$ \\
\hline Breathing difficulty & $26(34.7)$ & $2.6 \pm 2.2$ & $9.1 \pm 5.9$ \\
\hline
\end{tabular}


At the five-month follow-up, $62.6 \%$ $(47 / 75)$ of the patients had at least one unresolved symptom, most commonly fatigue $(57.3 \%, 43 / 75)$, smell and taste changes $(33.3 \%, 25 / 75$ and $10.6 \%, 8 / 75$ respectively), and breathing difficulties $(10.6 \%, 8 / 75)$. Fatigue, breathing difficulties, memory disorders and hair loss, were not typically reported during the initial follow-ups ("new symptoms"), while other symptoms such as muscle aches, headache and smell and taste changes usually started at the beginning of illness. Smell and taste changes appeared around the fourth day after disease onset, on average, were rarely the first symptoms to appear, and were among the longest lasting.

\section{DISCUSSION}

Since october 2020, we have been treating patients on daily basis for whom symptoms have not completely subsided, essentially younger population around 40 years old with no relevant medical history. While nasopharyngeal SARSCoV2 PCR can be still positive even after 30 days of onset symptoms we found no argument for a reinfection when repeating PCR testing (12).

Our study reveals that, headache, fever, and muscle aches were often the first symptoms to appear, while smell and taste changes were not. Fatigue was usually the first symptom. The mean duration of fever was the shortest, while the duration of smell and taste changes were the longest among symptoms prevalent in $>50 \%$ of the patients. More than half of the patients did not recover from all their symptoms five months after, most of them reporting fatigue, smell and taste changes, and breathing difficulties. These unresolved symptoms occurred together or separately, and some were not reported during the previous follow-ups.

Our findings are in-line with other longitudinal studies of mild COVID-19 patients, that also found high variability in the clinical course of the disease, and long durations (weeks after infection) of fatigue, shortness of breath and smell and taste changes $(13,14)$. In light of the limited data available for mild COVID-19 patients, especially in the long term, our study provides important inputs regarding the disease course over a five-month period in ambulatory patients.

This post-COVID-19 entity is worth addressing because we are facing an unprecedented pandemic, which explains why suddenly patients are all at the same time seeking care for what might otherwise be a banal chronic fatigue syndrome. Thereafter, a better understanding of this entity might help the medical community propose an adequate treatment that depends on the acknowledged physiopathology. Our study also had several limitations. The findings are relevant for mild patients only.

The results indicate that despite large variability in the symptoms' onset and duration, some symptoms (headache, fever, and muscle aches) are common as first symptoms. Fatigue, if occurs, usually appears as a first symptom. Taste and smell changes are not typically first, and are resolved either fast (within patients' infectious time of 10 days), or longer and gradually, with the longest averaged duration among all prevalent symptoms. At the five-month follow-up $62.6 \%(47 / 75)$ of patients experienced unresolved symptoms, with symptoms either continuing throughout the illness (e.g., smell and taste changes), or appearing as new symptoms (e.g hair loss).

This information regarding the duration of the patients' symptoms might help understand COVID-19 long-term health complications, reduce the level of anxiety of patients, or legitimize their concerns when needed. This study paves the way for future long-term COVID-19 studies, and advances towards better understanding and management of the disease. This post-COVID-19 entity is worth addressing because we are facing an unprecedented pandemic, which explains why suddenly patients are all at the same time seeking care for what might otherwise be a banal chronic fatigue syndrome.

We agree with there is a need for more sophisticated categorization of post-COVID-19 symptoms. Complex symptoms such as fatigue and breathle- ssness, in many cases, may be multifactorial (15). After 4-8 weeks, ongoing fatigue is present in more than two thirds, followed by breathlessness and symptoms of post-traumatic stress disorder (16).

Symptoms are as markedly heterogeneous as seen in acute COVID-19 and may be constant, fluctuate, or appear and be replaced by symptoms relating to other systems with varying frequency. Such multisystem involvement requires a holistic approach to management of long-COVID. Mainstream media are giving publicity to patient-coined terms 'long COVID' and 'long-haul COVID' (17). Following the initial surge of infections, focus shifted to managing the longer-term sequelae of illness in survivors. 'Post-acute COVID' (known colloquially as 'long COVID') is emerging as a prevalent syndrome. It encompasses a plethora of debilitating symptoms (including breathlessness, chest pain, palpitations, and orthostatic intolerance) which can last for weeks or more following mild illness (18).

Patients should have long-term access to multidisciplinary health care, including rehabilitation services, social and financial support. Long COVID affects even young adults, so effective public health messaging for such individuals about the risks of infection is warranted. Primary care services need the capacity to deal with patients with long COVID. Finally, health-care workers themselves are likely to have a high burden of long COVID (19).

\section{CONCLUSION}

Persistent symptoms after mild COVID-19 manifested in over half of the participants reporting at least one unresolved symptom after five months. Thereafter, a better understanding of this entity might help the medical community propose an adequate treatment that depends on the acknowledged physiopathology.

\section{NOVČANA POTPORA/FUNDING} Nema/None

ETIČKO ODOBRENJE/ETHICAL APPROVAL Nije potrebno/None 


\section{SUKOB INTERESA/CONFLICT OF INTEREST} Autori su popunili the Unified Competing Interest form na www.icmje.org/coi_disclosure.pdf (dostupno na zahtjev) obrazac i izjavljuju: nemaju potporu niti jedne organizacije za objavljeni rad; nemaju financijsku potporu niti jedne organizacije koja bi mogla imati interes za objavu ovog rada u posljednje 3 godine; nemaju drugih veza ili aktivnosti koje bi mogle utjecati na objavljeni rad./ All authors have completed the Unified Competing Interest form at www.icmje.org/coi disclosure. pdf (available on request from the corresponding author) and declare: no support from any organization for the submitted work; no financial relationships with any organizations that might have an interest in the submitted work in the previous 3 years; no other relationships or activities that could appear to have influenced the submitted work.

\section{LITERATURE}

1. World Health Organization, December 30th, 2020

2. Symptoms of Coronavirus CDC n.d. https:// www.cdc.gov/coronavirus/2019-ncov/symptoms-testing/symptoms.html (accessed March 1, 2021.)

3. Clinical Spectrum of SARS-CoV-2 Infection. NIH COVID-19 treatment guidelines. https:// www.covid19treatmentguidelines.nih.gov/ overview/clinical-spectrum/ (accessed October 11, 2021.)

4. Tenforde M.W., Kim S.S., Lindsell C.J. Symptom Duration and Risk Factors for Delayed Return to Usual Health Among Outpatients with COVID-19 in a Multistate Health Care Systems Network - United States, March-June 2020. MMWR Morb Mortal Wkly Rep. 2020; 69 (30): 993-8.

5. Marshall M. The lasting misery of coronavirus long-haulers. Nature. 2020; 585 (7825): 339-41.
6. The Lancet Facing up to long COVID. Lancet. 2020; 396 (10266): 1861.

7. Eshak N., Abdelnabi M., Ball S. Dysautonomia: An Overlooked Neurological Manifestation in a Critically ill COVID-19 Patient. Am J Med Sci. 2020; 360 (4): 427-9.

8. Davido B., Seang S., Tubiana R., de Truchis P. Post-COVID-19 chronic symptoms: a postinfectious entity? Clin Microbiol Infect. 2020; 26 (11): 1448-9.

9. Vaira L.A., Salzano G., Deiana G., De Riu G. Laryngoscope; 2020. Anosmia and ageusia: common findings in COVID-19 Patients.

10. Speth M.M., Singer-Cornelius T., Oberle M., Gengler I., Brockmeier S.J., Sedaghat A.R. Olfactory Dysfunction and Sinonasal Symptomatology in COVID-19: Prevalence, Severity, Timing, and Associated Characteristics. Otolaryngol Head Neck Surg. 2020; 163 (1): 114-20.

11. Carfì A., Bernabei R., Landi F. Gemelli Against COVID-19 Post-Acute Care Study Group. Persistent Symptoms in Patients After Acute COVID-19. JAMA. 2020; 324 (6): 603-5.

12. Lan L., Xu D., Ye G., Xia C., Wang S., Li Y. Positive RTPCR test results in patients recovered from COVID-19. JAMA. 2020; 323: 1502-3.

13. Mizrahi B., Shilo S., Rossman H. Longitudinal symptom dynamics of COVID-19 infection. Nat Commun. 2020; 11 (1): 6208.

14. Nehme M., Braillard O., Alcoba G. COVID-19 Symptoms: Longitudinal Evolution and Persistence in Outpatient Settings (published online ahead of print, 2020 Dec 8) Ann Intern Med. 2020; M20-M5926.

15. Halpin S, O'Connor R, Sivan M. Long COVID and chronic COVID syndromes. J Med Virol. 2021; 93 (3): 1242-3.
16. Halpin SJ, McIvor C, Whyatt G, et al. Postdischarge symptoms and rehabilitation needs in survivors of COVID-19 infection: A cross-sectional evaluation. J Med Virol 2020, in press ( 10.1002/jmv.26368).

17. Gross A. Fatigue plagues thousands suffering post-coronavirus symptoms. Financial Times, 3 August 2020.

18. Dani M, Dirksen A, Taraborrelli P, Torocastro M, Panagopoulos D, Sutton R, Lim PB. Autonomic dysfunction in 'long COVID': rationale, physiology and management strategies. Clin Med (Lond). 2021; 21 (1): 63-7.

19. The Lancet. Facing up to long COVID. Lancet. 2020; 396 (10266): 1861. 
Sažetak

\title{
NERAZJAŠNJENI SIMPTOMI U ODRASLOJ POPULACIJI NAKON BLAGE SARS-COV2 INFEKCIJE
}

\author{
Amina Šeta, Senka Dinarević-Mesihović, Timur Šečić, Miralem Đešević
}

Uvod: Infekcija korona virusom (SARS-CoV2) u posljednjih godinu i pol dana postala je svjetska pandemija. Simptomi COVID-19 i njihova težina i trajanje uveliko se razlikuju, sa sve većim brojem pacijenata s perzistirajućim i dugotrajnim simptomima.

Cilj: Cilj ove studije je okarakterizirati perzistirajuće simptome kod pacijenata s blagim oblikom COVID-19 tijekom pet mjeseci nakon početka bolesti i potencijalno pomoći u menadžmentu ovih pacijenata.

Metode: Sedamdeset i pet odraslih pacijenata bilo je uključeno u studiju u periodu od listopada 2020. do ožujka 2021. u PZU Eurofarm Centar. Kriteriji za uključivanje zahtijevali su da su pacijenti stariji od 18 godina, s pozitivnim rezultatima PCR testa na SARS-CoV2 i blagim simptomima koji nisu zahtijevali hospitalizaciju. Analizirani su pojava, trajanje i rješavanje simptoma.

Rezultati: 74,7\% (56/75), 69,3\% (52/75), 66,7\% (50/75) i 40,0\% (30/75) pacijenata imalo je sljedeće simptome: glavobolju, povišenu tjelesnu temperaturu, bolove u mišićima i suhi kašalj. Umor je bio prisutan kod većine pacijenata, točnije kod 74,7\% (56/75). Promjene mirisa i okusa zabilježene su 3,9 2,4, odnosno 4,6 \pm 3,7 dan od početka bolesti. Među najčešćim simptomima, stanje povišene tjelesne temperature je imalo najkraće trajanje (3,8 $\pm 1,6$ dana), a promjene ukusa i mirisa bile su najtrajniji simptomi (22,2 \pm 17,6 i 26,9 \pm 19,7 dana). Tijekom petomjesečnog praćenja, 62,6\% (47/75) pacijenata imalo je barem jedan neriješeni perzistirajući simptom, najčešće umor (57,3\%, 43/75), promjene mirisa i okusa (33,3\%, 25/75 i 10,6\%, odnosno 8/75) i poteškoće $s$ disanjem $(10,6 \%, 8 / 75)$.

Zaključak: Perzistentni simptomi nakon blage infekcije COVID-19 manifestirali su se kod više od polovice pacijenata koji su prijavili barem jedan neriješeni simptom pet mjeseci nakon infekcije.

Ključne riječi: COVID-19, SARS-COV2, TRAJANJE SIMPTOMA, NERIJEŠENI SIMPTOMI

Primljeno/Received: 13. 8. 2021

Prihvaćeno/Accepted: 14. 10. 2021. 